Article

\title{
Two Reliable Methodical Approaches for Non-Invasive RHD Genotyping of a Fetus from Maternal Plasma
}

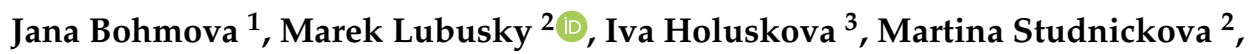 \\ Romana Kratochvilova ${ }^{1}$, Eva Krejcirikova ${ }^{1}$, Veronika Durdova ${ }^{2}$, Tereza Kratochvilova ${ }^{2}$, \\ Ladislav Dusek ${ }^{4}$, Martin Prochazka ${ }^{1}$ and Radek Vodicka ${ }^{1, *}$ \\ 1 Department of Medical Genetics, University Hospital Olomouc and Faculty of Medicine and Dentistry, \\ Palacky University Olomouc, 77520 Olomouc, Czech Republic; jana.bohmova@fnol.cz (J.B.); \\ romana.kratochvilova@fnol.cz (R.K.); eva.krejcirikova@fnol.cz (E.K.); martin.prochazka@fnol.cz (M.P.) \\ 2 Department of Obstetrics and Gynecology, University Hospital Olomouc and Faculty of Medicine \\ and Dentistry, Palacky University Olomouc, 77520 Olomouc, Czech Republic; marek@lubusky.com (M.L.); \\ martina.studnickova@fnol.cz (M.S.); veronika.durdova@fnol.cz (V.D.); tereza.kratochvilova@fnol.cz (T.K.) \\ 3 Department of Blood Transfusion, University Hospital and Palacky University Olomouc, 77520 Olomouc, \\ Czech Republic; iva.holuskova@fnol.cz \\ 4 Institute of Biostatistics and Analyses, Masaryk University, 62500 Brno, Czech Republic; \\ ldusek@med.muni.cz \\ * Correspondence: vodickar@fnol.cz; Tel.: +420-588-444-636
}

Received: 28 June 2020; Accepted: 30 July 2020; Published: 5 August 2020

\begin{abstract}
Noninvasive fetal RHD genotyping is an important tool for predicting RhD incompatibility between a pregnant woman and a fetus. This study aimed to assess a methodological approach other than the commonly used one for noninvasive fetal RHD genotyping on a representative set of RhD-negative pregnant women. The methodology must be accurate, reliable, and broadly available for implementation into routine clinical practice. A total of $337 \mathrm{RhD}$-negative pregnant women from the Czech Republic region were tested in this study. The fetal RHD genotype was assessed using two methods: real-time PCR and endpoint quantitative fluorescent (QF) PCR. We used exon-7-specific primers from the RHD gene, along with internal controls. Plasma samples were analyzed and measured in four/two parallel reactions to determine the accuracy of the RHD genotyping. The RHD genotype was verified using DNA analysis from a newborn buccal swab. Both methods showed an excellent ability to predict the RHD genotype. Real-time PCR achieved its greatest accuracy of $98.6 \%$ ( $97.1 \%$ sensitivity and $100 \%$ specificity $(95 \% \mathrm{CI})$ ) if all four PCRs were positive/negative. The QF PCR method also achieved its greatest accuracy of $99.4 \%$ (100\% sensitivity and $98.6 \%$ specificity $(95 \% \mathrm{CI}))$ if all the measurements were positive/negative. Both real-time PCR and QF PCR were reliable methods for precisely assessing the fetal $R H D$ allele from the plasma of $\mathrm{RhD}$-negative pregnant women.
\end{abstract}

Keywords: non-invasive fetal genotyping; RHD gene; cell-free fetal DNA; real-time PCR; QF PCR; $\mathrm{Rh}$ blood group system; red blood cell alloimmunization; hemolytic disease of the fetus and newborn

\section{Introduction}

Alloimmunization of RhD-negative pregnant women by the highly immunogenic fetal D antigen leads to a hemolytic transfusion reaction and hemolytic disease of the fetus and newborn. For this reason, anti-D immune prophylaxis is preventively administered to $\mathrm{RhD}$-negative pregnant women [1-3]. By conducting a molecular analysis of cell-free fetal DNA (cffDNA) circulating in the peripheral blood of a pregnant woman, it is possible to determine the fetal RHD genotype at an early stage of pregnancy. 
Early determination of the fetal RHD genotype allows for the targeted use of antenatal prophylaxis and the prevention of unnecessary prophylaxis of RhD-negative pregnant women with RhD-negative fetuses. These women are not at risk of immunization and valuable and limited immunoglobulin against $\mathrm{D}$ antigen is being spared $[4,5]$.

In the Czech Republic, all pregnant women undergo a red blood cell antibody screening in the first trimester. The screening is positive in about $5 \%$ of women (5000 women a year in the Czech Republic), but the clinically significant alloantibody is identified in only about $1.5 \%$ of them (1500 women a year). The fetus is at risk for hemolytic disease only if the complementary antigen is present on their erythrocytes. This is the case in about $0.5 \%$ of them (500 fetuses a year). The presence of the complementary antigen can be assessed noninvasively by genotyping using cffDNA circulating in the peripheral blood of pregnant women [6].

Identification of the presence of the RHD gene in the fetus is based on the detection of unique sequences from the RHD gene, especially exon 7 [7]. The RHD negative genotype in the White population and thus the absence of $\mathrm{D}$ antigen in the erythrocyte membrane is due to the deletion of the RHD gene in the homozygous state. Non-cellular fragmented fetal DNA present in the plasma of pregnant women is used for non-invasive prenatal RHD genotyping of the fetus. The percentage of cffDNA in the plasma of pregnant women is very variable and most often ranges from 5 to $10 \%$ depending on the duration of pregnancy, the size of the placenta, the weight of the woman and fetus, pathological pregnancy, etc. [8]. The aim is to diagnose the fetal RHD genotype at an early stage of pregnancy; therefore, it is necessary to use a sensitive method for the detection. The most commonly used method is real-time polymerase chain reaction (PCR) [9-15]. For non-invasive RHD determination of the fetal status, it is also possible to use mini-sequencing [16], emulsion digital PCR (droplet digital PCR, ddPCR) [17,18], quantitative fluorescence PCR (QF PCR) with detection by capillary electrophoresis [19], and massive parallel sequencing [20-22].

No representative study has yet been performed in the Czech Republic on a large set of samples to assess the suitability of particular non-invasive RHD genotyping methods for introduction into routine clinical practice.

The aim of this study was to assess two methodological approaches for noninvasive fetal RHD genotyping on a representative set of RhD-negative pregnant women:

(1) Commonly used real-time PCR (determining fetal RHD genotype via TaqMan real-time PCR using internal amplification control).

(2) Endpoint QF PCR (determining fetal RHD genotype using endpoint QF PCR using internal amplification control with capillary electrophoresis).

The methodology must be accurate, reliable, and broadly available for implementation into routine clinical practice.

\section{Materials and Methods}

\subsection{Study Design}

This work was a prospective cohort (non-randomized) study. Randomization was not needed because we did not make any conclusions regarding the RHD genotype prevalence in the population.

\subsection{Sample Collection}

Pregnant women were serologically tested to be enrolled in the study. The examination for the non-presence/presence of the " $\mathrm{D}$ " antigen on erythrocytes of a pregnant woman was performed with two monoclonal diagnostic sera of anti-D class IgM with different clones that do not detect the D category VI (DVI) variant. The examination was performed using the agglutination method on microtiter plates or in a test tube. 
Peripheral blood samples of RhD-negative pregnant women, confirmation samples of newborn buccal swabs, and control plasma samples for calibration and optimization were collected in collaboration with the Department of Medical Genetics, the Department of Obstetrics and Gynecology, and the Department of Transfusion Medicine of the University Hospital Olomouc. All of the women enrolled in the study signed an informed consent form approved by the Ethics Committee of the University Hospital Olomouc (approval code: 150/10; approved on 20 September 2010).

The total number of analyzed samples was 337 triplets when it was possible to examine a pregnant woman, a fetus, and a newborn as a control of the fetal RHD genotype together. The mothers had already been phenotypically (serologically) and genotypically tested so newborn phenotyping was not performed in this study. The real-time PCR and QF PCR analyses were performed in randomly selected plasma samples taken from RhD-negative pregnant women $>18$ years old with a singleton pregnancy. The characterizations of the tested RhD-negative pregnant women are in Table 1. Determination of the fetal RHD genotype was evaluated in parallel using two methods: TaqMan real-time PCR and endpoint QF PCR.

Table 1. Characterization of the sample collection.

\begin{tabular}{|c|c|c|c|c|c|c|c|c|c|c|c|}
\hline \multirow{2}{*}{$\begin{array}{c}\text { RhD-Negative } \\
\text { Pregnant } \\
\text { Women }^{1}\end{array}$} & \multirow{2}{*}{$n=337$} & \multirow{2}{*}{$\begin{array}{c}\text { Gestation } \\
\text { Week }\end{array}$} & \multicolumn{2}{|c|}{$\begin{array}{c}\text { Gestation } \\
\text { Week }\end{array}$} & \multirow{2}{*}{ Age } & \multicolumn{2}{|c|}{ Age } & \multirow{2}{*}{ BMI } & \multicolumn{2}{|c|}{ BMI } & \multirow{2}{*}{$\begin{array}{c}\text { Ethnic Group } \\
\text { of } \\
\text { Participants }\end{array}$} \\
\hline & & & Median & Mean & & Median & Mean & & Median & Mean & \\
\hline II. Trimester & $66(20 \%)$ & $14-23$ & 15 & 15.5 & $18-43$ & 29 & 30 & $17-36$ & 23 & 24.3 & Caucasian \\
\hline
\end{tabular}

\subsection{Sample Preparation and DNA Isolation}

All 337 blood samples from RhD-negative pregnant women were collected into two parallel $9 \mathrm{~mL}$ tubes ("A" and "B") containing ethylenediaminetetraacetic acid (EDTA). Anticoagulated blood was placed on ice immediately after collection and was processed within $4 \mathrm{~h}$ after sampling. Plasma was separated from the cellular fraction of blood using double centrifugation $(2700 \times g$ for $10 \mathrm{~min}$ and $3500 \times g$ for $20 \mathrm{~min}$ ). The plasma samples were frozen until further processing at $-28{ }^{\circ} \mathrm{C}$. Plasma-cell-free (cf) DNA was isolated in each of the two parallel tubes (" $\mathrm{A}$ " and "B"). The DNA isolation of $1 \mathrm{~mL}$ of plasma was performed using the QIAamp DNA Mini Kit (Qiagen, Venlo, The Netherlands). The incubation step for the isolation took place at $56^{\circ} \mathrm{C}$, with an elution volume of $65 \mu \mathrm{L}$. The isolation of maternal DNA from peripheral blood leukocytes was performed with a Qiacube automated isolator (Qiagen) using the QIAamp DNA mini kit (Qiagen), according to the manufacturer's instructions. The isolation of the control DNA from newborn buccal swabs was performed using the QIAamp DNA Mini kit (Qiagen), according to the manufacturer's instructions.

\subsection{Determination of Fetal RHD Genotype by TaqMan Real-Time PCR Using Internal Amplification Control}

Plasma DNA (" $\mathrm{A}$ " and " $\mathrm{B}$ ") were analyzed from each sample in two parallel reactions (each cffDNA sample was measured four times). The maternal RHD genotype was determined from the DNA sample from peripheral blood leukocytes and the fetal genotype was confirmed from a neonatal buccal swab. Specific primers for exon 7 and for the internal control were used to amplify and quantify the multiplex using the TaqMan real-time PCR system, where their sequences were: 5'-GGGTGTTGTAACCGAGTGCTG-3' , forward and 5'-CCGGCTCCGACGGTATC-3', reverse. The sequence and labeling of the TaqMan probe for RHD exon 7 was $5^{\prime}$-FAMCCCACAGCTCCATCATGGGCTACAA-BHQ1-3'. 
The primer and probe sequences from the $\beta$-globin gene for the internal total plasma DNA amplification control were GTGCACCTGACTCCTG AGGAGA, forward, CCTTGATACCAACCTGCCCAG, reverse, and 5'-JOE-AAGGTGAACGTGGATGAAGTTGGTGG -BHQ1-3', TaqMan probe.

The PCR reactions for DNA isolated from the plasma of RhD-negative pregnant women were amplified in a final $25 \mu \mathrm{L}$ volume. PCR premix contained $12.5 \mu \mathrm{L}$ of Mastermix (Thermo Scientific Maxima Probe/ROX qPCR Master Mix (2×), Thermo Fisher Scientific, Waltham, MA, USA), $0.15 \mu \mathrm{L}$ 10× ROX (Thermo Scientific Maxima Probe/ROX qPCR Master Mix (2x)), $1.5 \mu \mathrm{L}$ forward and reverse multiplexed primers (primer concentration for RHD exon 7 was $10-20 \mathrm{pmol} / \mathrm{L}^{-1}$, primer concentration for $\beta$-globin was $10 \mathrm{pmol} / \mathrm{L}^{-1}$ ) (Sigma-Aldrich, St. Louis, MO, USA), $1 \mu \mathrm{L}$ of multiplexed TaqMan probes (probe concentration for RHD exon 7 was $10-20 \mathrm{pmol} / \mathrm{L}^{-1}$ and for $\beta$-globin was $10 \mathrm{pmol} / \mathrm{L}^{-1}$ ) (Sigma-Aldrich), and $8.5 \mu \mathrm{L}$ DNA.

The PCR premix for DNA isolated from the leukocytes of the RhD-negative pregnant women and for control DNA from the neonatal buccal swabs were amplified in a final $12.5 \mu \mathrm{L}$ volume. The PCR premix contained 6.25 $\mu \mathrm{L}$ of Mastermix (Thermo Scientific Maxima Probe/ROX qPCR Master Mix $(2 \times)), 0.075 \mu \mathrm{L} 10 \times$ ROX (Thermo Scientific Maxima Probe/ROX qPCR Master Mix $(2 \times)$ ), $0.75 \mu \mathrm{L}$ forward and reverse multiplexed primers (primer concentration for $R H D$ exon 7 was $10-20 \mathrm{pmol} / \mathrm{L}^{-1}$ ), primer concentration for $\beta$-globin was $10 \mathrm{pmol} / \mathrm{L}^{-1}$ ) (Sigma-Aldrich), $0.5 \mu \mathrm{L}$ of multiplexed TaqMan probes (probe concentration for RHD exon 7 was $10-20 \mathrm{pmol} / \mathrm{L}^{-1}$ and for $\beta$-globin was $10 \mathrm{pmol} / \mathrm{L}^{-1}$ ) (Sigma-Aldrich), $3.25 \mu \mathrm{L}$ PCR water (Top-Bio, Prague, Czech Republic), and $1 \mu \mathrm{L}$ DNA.

DNA samples isolated from $R H D$-positive blood and RHD-positive fetal DNA isolated from plasma were used as amplification controls. PCR water was used to control the contamination of the PCR premixes. Amplification for all samples was performed in a real-time PCR system Mx3005P (Stratagene, Santa Clara, CA, USA) under the following conditions: $95^{\circ} \mathrm{C} 15 \mathrm{~min},\left(95^{\circ} \mathrm{C} 15 \mathrm{~s}, 60^{\circ} \mathrm{C}\right.$ 60 s) 55x. The software Prox-Mx3005P v3.00 Build 311 (Stratagene) was used for the evaluation. The threshold cycle $(\mathrm{Ct})$ values (the number of cycles at which the fluorescence exceeds the threshold value) were determined for each group of samples. Before reading, the measured fluorescence was logarithmized.

Within four parallel measurements, four criteria for evaluating positivity and negativity were set:

- Criterion 1-Positive if all four plasmas were positive, negative if all four plasmas were negative.

- Criterion 2-Positive if three or more plasmas were positive, negative if two or more plasmas were negative.

- Criterion 3-Positive if three or more plasmas are positive, negative if three or more plasmas were negative.

- Criterion 4-Positive if two or more plasmas were positive, negative if three or more plasmas were negative.

\subsection{Determination of Fetal RHD Genotype with Endpoint QF PCR Using Internal Amplification Control with} Capillary Electrophoresis

Plasma DNA ("A" and "B") was analyzed in two parallel reactions. Specific primers for exon 7 of the RHD gene and for AMELX/Y sequences were used to amplify and quantify the multiplex using endpoint QF PCR. The sequence and labeling of the primers for $R H D$ exon 7 were $5^{\prime}$-HEX-CCCTGGGCTCTGTAAAG-3', forward, and 5'-CCGGCTCCGACGGTATC-3', reverse. The primers for the AMELX/Y gonosomal sequences were used as internal amplification controls, where their sequences were: 5'-6FAM-CCCTGGGCTCTGTAAAG-3', forward, and 5' ATCAGAGCTTAAACTGGGAAGCT- ${ }^{\prime}$, reverse. The PCR reactions for DNA isolated from the plasma of the RhD-negative pregnant women were amplified in a final $20 \mu \mathrm{L}$ volume.

The PCR premix contained $10 \mu \mathrm{L}$ Combi PPP Master Mix (Top-Bio), $1 \mu \mathrm{L}$ forward and reverse multiplexed primers (primer concentration for RHD exon 7 was $10 \mathrm{pmol} / \mathrm{L}^{-1}$, primer concentration for AMELX/Y was $10 \mathrm{pmol} / \mathrm{L}^{-1}$ ) (Sigma-Aldrich), and $9 \mu \mathrm{L}$ DNA. 
The PCR premix for DNA isolated from leukocytes of the RhD-negative pregnant women and for control DNA from the neonatal buccal swabs were amplified in a final $10 \mu \mathrm{L}$ volume. The PCR premix contained $5 \mu \mathrm{L}$ Combi PPP Master Mix (Top-Bio), $0.5 \mu \mathrm{L}$ forward and reverse multiplexed primers (primer concentrations for RHD exon 7 was $10 \mathrm{pmol} / \mathrm{L}^{-1}$, the primer concentration for AMELXY was $10 \mathrm{pmol} / \mathrm{L}^{-1}$ ) (Sigma-Aldrich), $3 \mu \mathrm{L}$ PCR water (Top-Bio), and $1.5 \mu \mathrm{L}$ DNA.

DNA samples isolated from the RHD-positive blood and RHD-positive fetal DNA isolated from plasma were used as the amplification controls. PCR water was used to control for the contamination of PCR premixes. PCR conditions were $95^{\circ} \mathrm{C} 10 \mathrm{~min},\left(94{ }^{\circ} \mathrm{C} 30 \mathrm{~s}, 59^{\circ} \mathrm{C} 60 \mathrm{~s}, 72{ }^{\circ} \mathrm{C} 60 \mathrm{~s}\right) 35-40 \times, 72{ }^{\circ} \mathrm{C}$ $10 \mathrm{~min}, 60^{\circ} \mathrm{C} 30 \mathrm{~min}$. PCR amplification was performed for all samples in a Thermocycler C 1000 (Bio-Rad, Hercules, CA, USA).

The fluorescence intensity and size of the PCR products were determined using capillary electrophoresis on an ABI PRISM 3130 Genetic Analyzer (Applied Biosystems, Waltham, MA, USA) using polymer POP-4 (Applied Biosystems) and a $47 \mathrm{~cm}$ capillary with a diameter of 50

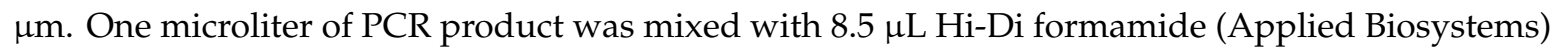
and the GeneScan 500 TAMRA Size Standard (Applied Biosystems). Each sample of plasma cffDNA was assessed in two capillary electrophoresis conditions. The first injection was for $4 \mathrm{~s}$ at $4 \mathrm{kV}$ with electrophoresis for $18 \mathrm{~min}$ at $15 \mathrm{kV}$, and the second injection was for $5 \mathrm{~s}$ at $10 \mathrm{kV}$ with electrophoresis for $18 \mathrm{~min}$ at $15 \mathrm{kV}$. The capillary conditions for peripheral blood samples and buccal swab samples were injected for $5 \mathrm{~s}$ at $10 \mathrm{kV}$ with electrophoresis for $18 \mathrm{~min}$ at $15 \mathrm{kV}$. The data were analyzed using 310 GeneScan 3.1.2 software (Applied Biosystems). The RFU (relative fluorescence unit) parameter expressed as a peak height was used for quantitative analyses. QF PCR was evaluated with two replicates as we had a limited amount of total plasma DNA.

Within two parallel measurements, two criteria for evaluating positivity and negativity were set:

- $\quad$ Criterion 1-Positive if two plasmas were positive, negative if two plasmas were negative.

- Criterion 2-Positive if one plasma was positive, negative if two plasmas were negative.

\subsection{Data Collection}

Data from plasma DNA were analyzed, evaluated, and collected independently from the newborn DNA ones.

\subsection{Study Limitation}

The data from the evaluation of pregnancy and clinical characteristics associated with plasma or cffDNA concentrations were not available. We did not carry out the molecular analysis of weak RHD variants.

\subsection{Statistical Evaluation}

Standard descriptive statistics were applied in the analysis: arithmetic mean with standard deviation (SD) and median with a 5th to 95th percentile range were adopted for the continuous variables and absolute and relative frequencies were adopted for categorical variables.

Fisher's exact test was applied for the computation of the statistical significance of relations between categorical variables (association analyses).

The predictive power of variables was quantified on the basis of a standard set of statistics: AUC and its statistical significance derived from ROC analysis, specificity, sensitivity, NPV, PPV, and overall accuracy; ROC analysis was applied for the identification of optimal cut-offs of continuous variables as predictors.

Analyses were computed using SPSS 23.0.0.1 (IBM Corporation, 2015, Armonk, NY, USA). 


\section{Results}

\subsection{TaqMan Real-Time PCR}

Determination of the fetal RHD genotype was possible in a total of 333 out of the 337 triplets using real-time PCR. The analysis failed in two plasma samples. The signal intensity of the PCR products from the RHD gene and from the internal control $\beta$-globin gene was not detectable in these samples. The analysis was not possible, probably due to the low concentration of cffDNA in the plasma, maybe due to DNA degradation. Determination of the fetal $R H D$ genotype was not possible in two samples due to repeated $R H D$-positive findings in the maternal DNA. Examples of the output of RHD-positive and $R H D$-negative fetuses using the probe for RHD exon 7 from real-time PCR are shown in Figure 1.

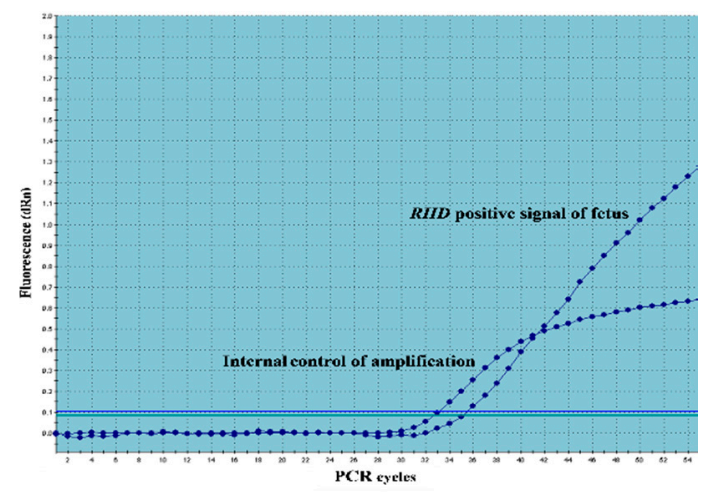

(a)

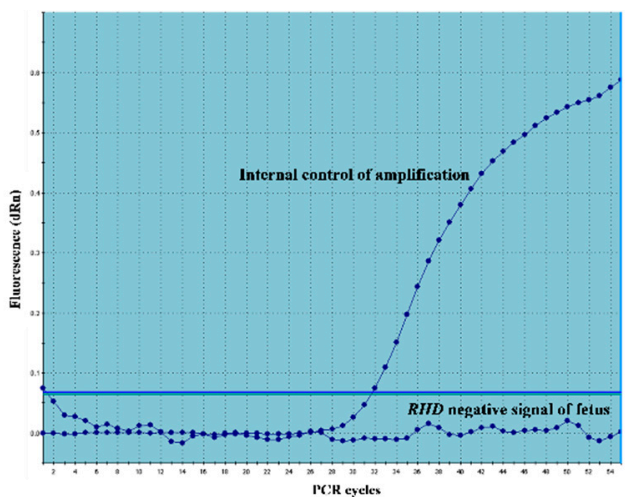

(b)

Figure 1. Example of the determination of $R H D$-positive and $R H D$-negative fetus using real-time PCR. Amplification curves show the fluorescence intensity of the probes as a function of the number of PCR cycles (Ct). (a) Example of an RHD-positive fetus: The $R H D$-positive signal of the fetus was detected by the probe for RHD exon 7 . The internal control of the amplification was detected using a probe for $\beta$-globin. (b) Example of an RHD-negative fetus: No signal of an RHD exon 7 probe was detected. The internal control of the amplification was detected using a probe for $\beta$-globin.

The predictive power of the diagnostic test and ROC analysis with cut-off $\mathrm{Ct}$ values are available in Tables 2 and 3. It was not possible to evaluate all of the data for any of the four assessed criteria (Tables 2 and 3). In the real-time PCR method, the greatest power to predict the RHD genotype was with criterion 1 (Table 2). ROC analysis and predictive values using the indentified cut-offs showed the best accuracy if the mean of all four parameters with a cut-off (Ct RHD-Ct globin) of 16.314 was calculated (Table 3). 
Table 2. Predictive power of the diagnostic test combinations.

\begin{tabular}{|c|c|c|c|c|c|c|c|c|c|c|c|}
\hline Criterions & Valid $n$ & $\begin{array}{c}\text { AUC } \\
(p \text {-Value })\end{array}$ & $\begin{array}{c}\text { True } \\
\text { Negative }\end{array}$ & $\begin{array}{c}\text { False } \\
\text { Negative }\end{array}$ & $\begin{array}{c}\text { False } \\
\text { Positive }\end{array}$ & $\begin{array}{c}\text { True } \\
\text { Positive }\end{array}$ & Specificity & Sensitivity & PPV & NPV & Accuracy \\
\hline Criterion 1 & $n=217$ & $0.985(<0.001)$ & $115(53.0 \%)$ & $3(1.4 \%)$ & $0(0.0 \%)$ & $99(45.6 \%)$ & 1.000 & 0.971 & 1.000 & 0.975 & 0.986 \\
\hline Criterion 2 & $n=322$ & $0.931(<0.001)$ & $147(45.7 \%)$ & $24(7.5 \%)$ & $0(0.0 \%)$ & $151(46.9 \%)$ & 1.000 & 0.863 & 1.000 & 0.860 & 0.925 \\
\hline Criterion 3 & $n=303$ & $0.975(<0.001)$ & $144(47.5 \%)$ & $8(2.6 \%)$ & $0(0.0 \%)$ & $151(49.8 \%)$ & 1.000 & 0.950 & 1.000 & 0.947 & 0.974 \\
\hline Criterion 4 & $n=327$ & $0.971(<0.001)$ & $144(44.0 \%)$ & $8(2.4 \%)$ & $2(0.6 \%)$ & $173(52.9 \%)$ & 0.986 & 0.956 & 0.989 & 0.947 & 0.969 \\
\hline
\end{tabular}

PPV—Positive predictive value; NPV—Negative predictive value; AUC-Area under the curve; Criterion 1—Positive if all four plasmas were positive, negative if all four plasmas were negative; Criterion 2-Positive if three or more plasmas were positive, negative if two or more plasmas were negative; Criterion 3-Positive if three or more plasmas were positive, negative if three or more plasmas were negative; Criterion 4-Positive if two or more plasmas were positive, negative if three or more plasmas were negative.

Table 3. ROC analysis of diagnostics tests and the predictive power of identified cut-offs.

\begin{tabular}{|c|c|c|c|c|c|c|c|c|c|c|c|c|}
\hline $\begin{array}{l}\text { Ct Differences of } \\
\text { RHD7 and Globin }\end{array}$ & Valid $n$ & $\begin{array}{c}\text { AUC } \\
(p \text {-Value })\end{array}$ & Cut-Off & $\begin{array}{c}\text { True } \\
\text { Negative }\end{array}$ & $\begin{array}{c}\text { False } \\
\text { Negative }\end{array}$ & $\begin{array}{c}\text { False } \\
\text { Positive }\end{array}$ & $\begin{array}{c}\text { True } \\
\text { Positive }\end{array}$ & Specificity & Sensitivity & PPV & NPV & Accuracy \\
\hline A1-Ct RHD7-Ct globin & $n=332$ & $\begin{array}{c}0.898 \\
(<0.001)\end{array}$ & -15.821 & $\begin{array}{c}140 \\
(42.2 \%)\end{array}$ & $22(6.6 \%)$ & $10(3.0 \%)$ & $\begin{array}{c}160 \\
(48.2 \%)\end{array}$ & 0.933 & 0.879 & 0.941 & 0.864 & 0.904 \\
\hline A2-Ct RHD7-Ct globin & $n=332$ & $\begin{array}{c}0.902 \\
(<0.001)\end{array}$ & -15.378 & $\begin{array}{c}138 \\
(41.6 \%)\end{array}$ & $19(5.7 \%)$ & $12(3.6 \%)$ & $\begin{array}{c}163 \\
(49.1 \%)\end{array}$ & 0.920 & 0.896 & 0.931 & 0.879 & 0.907 \\
\hline B1-Ct RHD7-Ct globin & $n=331$ & $\begin{array}{c}0.869 \\
(<0.001)\end{array}$ & -18.073 & $\begin{array}{c}141 \\
(42.6 \%)\end{array}$ & $32(9.7 \%)$ & $8(2.4 \%)$ & $\begin{array}{c}150 \\
(45.3 \%)\end{array}$ & 0.946 & 0.824 & 0.949 & 0.815 & 0.879 \\
\hline B2-Ct RHD7-Ct globin & $n=330$ & $\begin{array}{c}0.848 \\
(<0.001)\end{array}$ & -15.984 & $\begin{array}{c}141 \\
(42.7 \%)\end{array}$ & $33(10.0 \%)$ & $8(2.4 \%)$ & $\begin{array}{c}148 \\
(44.8 \%)\end{array}$ & 0.946 & 0.818 & 0.949 & 0.810 & 0.876 \\
\hline Mean of four parameters & $n=330$ & $\begin{array}{c}0.979 \\
(<0.001)\end{array}$ & -16.314 & $\begin{array}{c}144 \\
(43.6 \%)\end{array}$ & $8(2.4 \%)$ & $5(1.5 \%)$ & $\begin{array}{c}173 \\
(52.4 \%)\end{array}$ & 0.966 & 0.956 & 0.972 & 0.947 & 0.961 \\
\hline
\end{tabular}

PPV—Positive predictive value, NPV—Negative predictive value, AUC—Area under the curve. The optimal cut-off was defined by the maximal sum of sensitivity and specificity. 


\subsection{End-Point QF PCR}

Determination of the fetal RHD genotype was possible in a total of 335 out of 337 triplets using endpoint QF PCR. Determination of the fetal RHD genotype was not possible in two samples due to repeated RHD-positive findings in the maternal DNA. Examples of the electrophoretograms of RHD-positive and RHD-negative fetuses using the probes for RHD exon 7 and for AMELX/Y are shown in Figure 2.

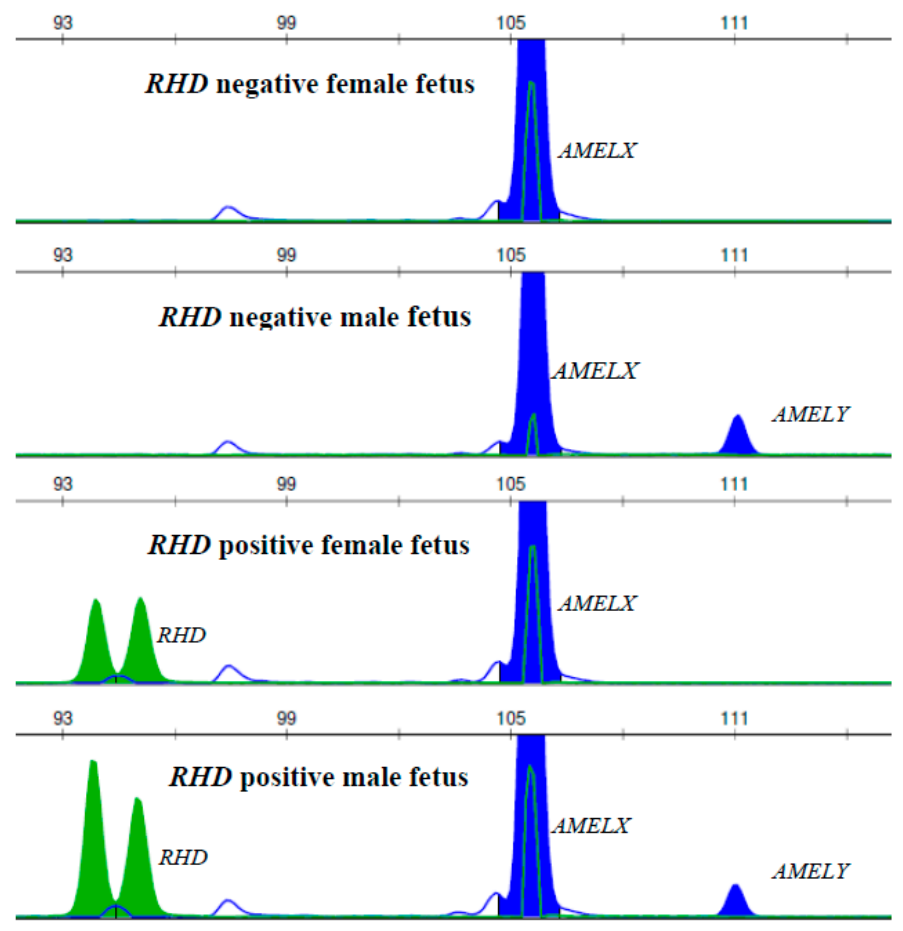

Figure 2. Example of the determination of RHD-positive and RhD-negative status and sex of the fetus using endpoint PCR with capillary electrophoresis. The RFU (relative fluorescence unit) parameter is expressed by green peak heights of RHD exon 7 and by blue peak heights of AMELX/Y gonosomal sequences (internal amplification controls).

The predictive power of the diagnostic test and ROC analysis with a cut-off of $\mathrm{Ct}$ values are shown in Tables 4 and 5. It was not possible to evaluate all of the data for any of the two assessed criteria (Tables 4 and 5). In endpoint QF PCR, the greatest power to predict RHD genotype was with criterion 1 (Table 4). The ROC analysis and predictive value using the identified cut-offs showed the best accuracy if the mean of all two parameters with a cut-off (RFU RHD/AMELX) of 0.023 was calculated (Table 5). 
Table 4. Predictive power of diagnostic test combinations.

\begin{tabular}{|c|c|c|c|c|c|c|c|c|c|c|c|}
\hline Criterions & Valid $n$ & $\underset{(p \text {-Value })}{\text { AUC }}$ & $\begin{array}{c}\text { True } \\
\text { Negative }\end{array}$ & $\begin{array}{c}\text { False } \\
\text { Negative }\end{array}$ & $\begin{array}{c}\text { False } \\
\text { Positive }\end{array}$ & $\begin{array}{c}\text { True } \\
\text { Positive }\end{array}$ & Specificity & Sensitivity & PPV & NPV & Accuracy \\
\hline Criterion 1 & $n=314$ & $\begin{array}{c}0.993 \\
(<0.001)\end{array}$ & $140(44.6 \%)$ & $0(0.0 \%)$ & $2(0.6 \%)$ & $172(54.8 \%)$ & 0.986 & 1.000 & 0.989 & 1.000 & 0.994 \\
\hline Criterion 2 & $n=329$ & $\begin{array}{c}0.976 \\
(<0.001)\end{array}$ & $140(42.6 \%)$ & $0(0.0 \%)$ & $7(2.1 \%)$ & $182(55.3 \%)$ & 0.952 & 1.000 & 0.963 & 1.000 & 0.979 \\
\hline
\end{tabular}

PPV—Positive predictive value; NPV—Negative predictive value; AUC-Area under the curve; Criterion 1—Positive if two plasmas were positive, negative if two plasmas were negative; Criterion 2-Positive if one or more plasmas were positive, negative if two or more plasmas were negative.

Table 5. ROC analysis of diagnostics tests and predictive power of identified cut-offs.

\begin{tabular}{|c|c|c|c|c|c|c|c|c|c|c|c|c|}
\hline $\begin{array}{l}\text { Ratio of RFU } \\
\text { RHD/AMELX }\end{array}$ & Valid $n$ & $\begin{array}{c}\text { AUC } \\
(p \text {-Value })\end{array}$ & Cut-Off & $\begin{array}{c}\text { True } \\
\text { Negative }\end{array}$ & $\begin{array}{c}\text { False } \\
\text { Negative }\end{array}$ & $\begin{array}{c}\text { False } \\
\text { Positive }\end{array}$ & $\begin{array}{c}\text { True } \\
\text { Positive }\end{array}$ & Specificity & Sensitivity & PPV & NPV & Accuracy \\
\hline RFU RHD/AMELX A1 & $n=328$ & $\begin{array}{c}0.987 \\
(<0.001)\end{array}$ & 0.011 & $\begin{array}{c}145 \\
(44.2 \%)\end{array}$ & $2(0.6 \%)$ & $2(0.6 \%)$ & $\begin{array}{c}179 \\
(54.6 \%)\end{array}$ & 0.986 & 0.989 & 0.989 & 0.986 & 0.988 \\
\hline RFU RHD/AMELX B1 & $n=327$ & $\begin{array}{c}0.972 \\
(<0.001)\end{array}$ & 0.001 & $\begin{array}{c}140 \\
(42.8 \%)\end{array}$ & $5(1.5 \%)$ & $7(2.1 \%)$ & $\begin{array}{c}175 \\
(53.5 \%)\end{array}$ & 0.952 & 0.972 & 0.962 & 0.966 & 0.963 \\
\hline Mean of two parameters & $n=326$ & $\begin{array}{c}0.992 \\
(<0.001)\end{array}$ & 0.023 & $\begin{array}{c}143 \\
(43.9 \%)\end{array}$ & $0(0.0 \%)$ & $4(1.2 \%)$ & $\begin{array}{c}179 \\
(54.9 \%)\end{array}$ & 0.973 & 1.000 & 0.978 & 1.000 & 0.988 \\
\hline
\end{tabular}

PPV—Positive predictive value, NPV—Negative predictive value, AUC-Area under curve. Optimal cut-off defined by the maximal sum of sensitivity and specificity. 


\section{Discussion}

Our study focused on comparing the commonly used TaqMan real-time PCR methodology with the less commonly used endpoint QF PCR with capillary electrophoresis. The sensitivity threshold using the TaqMan real-time PCR system was determined in our previous study. RHD calibration was performed using a dilution series of an artificial mixture of RHD genotypes. TaqMan real-time PCR was able to capture a $0.22 \%$ admixture of an RHD-positive heterozygote in an RHD-negative homozygote. The sensitivity of QF PCR was assessed using simulations of artificial mosaics of gonosomal sequences in the studies. Even a $0.5 \%$ mosaic was reliably captured using this method $[23,24]$. Both methodologies are therefore suitable for detecting fetal DNA fractions due to the highly sensitive detection limit (below 1\%). However, the sensitivity of the methodologies may also be affected by other factors, such as the overall concentration and quality of the fragmented cfDNA. The amount of total cfDNA was also affected by the time lag between the collection of peripheral blood into EDTA tubes and the separation of plasma from plasma cellular components. The amount of total cfDNA increased over time due to the lysis of peripheral leukocytes [25]. The lysis of maternal leukocytes leads to a relative decrease in the fetal fraction and an increase in the maternal fraction, which disrupts the subsequent quantitative analyses.

The typical fetal DNA fraction most often ranges between $5-15 \%$ of the total cfDNA across different gestational ages [26-30]. The mean percentage of the fetal fraction could be estimated to $7 \%(S D=0.09)$ in our study using the QF PCR ratio RFU RHD/(RFU AMELX-RFU RHD) from RHD-positive samples.

If it is not possible to process the blood within $6 \mathrm{~h}$ after the collection, it is advised to use specialized cfDNA preservation tubes (e.g., Cell-Free DNA BCT (Streck, La Vista, NE, USA), CellSave (Cell-Search, Huntingdon Valley, PA, USA), and PAXgene Blood DNA (Qiagen)), which prolong the stability of peripheral leukocytes and allow for storage of whole blood at room temperature for several days [31-33].

Barrett et al. reported that the concentration of short cffDNA fragments did not change at room temperature for $72 \mathrm{~h}$ when collected in Cell-Free DNA BCT tubes (Streck). In EDTA tubes, the number of long (maternal) DNA fragments increased after $72 \mathrm{~h}$ [34]. In our study, blood samples were separated within $4 \mathrm{~h}$ after collection, which is consistent with numerous studies that confirm that EDTA collection tubes provide cfDNA stability for at least $6 \mathrm{~h}$, and in some studies up to $24 \mathrm{~h}[33,35-38]$.

Plasma separation conditions can also affect the concentration and quality of cfDNA. The optimized centrifugation method allows for better separation of not only cellular components of blood, but also longer cfDNA fragments of maternal origin from shorter fetal DNA fragments. Commonly used methods are one-step centrifugation for $10 \mathrm{~min}$ at 2000-3000 $\mathrm{g}$ [39-41] or two-step centrifugation, where the first step is $1600-3000 \times g$ for $10 \mathrm{~min}$ and the second centrifugation is $10,000-16,000 \times g$ for $10 \mathrm{~min}$ [42-46]. The yield of cffDNA also depends on the chosen methodology for isolating cfDNA. The QIAamp Circulating Nucleic Acid Kit (Qiagen) is currently the most commonly used method for cffDNA isolation.

Jain et al. compared the use of kits for isolating viral DNA and circulating DNA using the QIAamp DSP Virus Kit and the QIAamp Circulating Nucleic Acid Kit. A statistically higher yield of cffDNA was achieved using the QIAamp Circulating Nucleic Acid Kit [47].

In our work, we used the QIAamp DNA Mini Kit (Qiagen, USA), the yield of which was sufficient due to the relatively easy evaluation of the detection of the presence of the RHD gene and due to the sensitivity of our methods. Our methodology for RHD genotyping using TaqMan real-time PCR and endpoint QF PCR was based on the detection of a unique exon 7 sequence that does not contain the highly homologous RHCE gene [7]. Functional (antigenic) variants of the Rh system are caused by insertions/deletions, single nucleotide polymorphisms, or gene conversion between RHD and RHCE genes $[48,49]$.

In Whites, the RhD-negative genotype is in most cases the result of a homozygous deletion of the entire RHD gene [50,51], which was confirmed by our study. The deletion of the RHD gene results 
from uneven recombination between two homologous $\mathrm{Rh}$ boxes of paired chromosomes 1 , leading to the formation of a hybrid Rh box [52].

It is reported that $12 \%$ to $18 \%$ of the White population has an RhD-negative genotype [53]. The expression of the $\mathrm{D}$ allele in the $\mathrm{D} / \mathrm{d}$ heterozygote is due to the dominant type of inheritance [51]. In the Black population, RHD is 5\% negative [53]. There are three common variants in the Black population that do not produce the $\mathrm{D}$ antigen. The most common cause of the $\mathrm{D}$ negative phenotype $(66 \%)$ is the presence of an RHD pseudogene (RHD ), which contains a 37 bp nucleotide duplication, resulting in the formation of a premature stop codon in exon 6 [54]. The second variant is the RHD-CE-D hybrid gene, which contains nucleotide sequences from the RHCE gene, does not produce antigen $\mathrm{D}$, and antigen $\mathrm{C}$ is formed abnormally. RHD-CE-D hybrid genes probably originated due to the pairing between RHD and RHCE genes on the same chromosome during meiosis and subsequent gene conversion [55,56]. The third variant is a complete deletion of the RHD gene, as in the White population [54].

The detection of the RHD gene deletion using exon 7 was shown to be sufficient for the Czech population in this study; for example, in contrast to the Black population, only two $(0.6 \%)$ discrepancies were found between the mother genotype and the phenotype in our group. We did not test other variants associated with RhD negatives. Our test is diagnostically suitable and usable for such populations in which the vast majority of RhD negativity is caused by the deletion of the entire gene, which is very accurately detectable by exon 7 .

For the populations in which several variants are responsible for RhD-negative status, other methods should be considered, for instance, the NGS (Next Generation Sequencing) method [57].

Currently, TaqMan real-time PCR is, due to its high sensitivity and specificity, the most common method for detecting the RHD allele of the fetus from free fetal DNA circulating in the peripheral blood of a pregnant woman. A general overview of currently used methods is given in Table 6 . In the Czech Republic, real-time PCR $[16,17,58]$ and droplet digital (dd) PCR [16] are used for non-invasive prenatal testing of the fetal RHD allele. Our study showed that the endpoint QF PCR method can fully replace real-time PCR. In the case of RHD-positive or male-specific fetuses, the amount of fetal fraction can be also relatively easily estimated.

Table 6. Methods used for noninvasive prenatal RHD genotyping.

\begin{tabular}{|c|c|c|c|c|}
\hline Methods & Study & $\mathbf{n}$ & $\begin{array}{l}\text { Sensitivity in \% } \\
(95 \% \mathrm{CI}) *\end{array}$ & $\begin{array}{l}\text { Specificity in \% } \\
(95 \% \mathrm{CI}) *\end{array}$ \\
\hline \multirow[t]{6}{*}{ Real-time PCR } & De Haas 2016 [9] & 25,789 & $99.9(99.9,100)$ & $97.7(97.4,98.0)$ \\
\hline & Haimila 2017 [10] & 10,814 & $100(99.9,100)$ & $99.8(99.6,99.9)$ \\
\hline & Hyland 2017 [11] & 599 & $100(99.0,100)$ & $99.6(97.6,100)$ \\
\hline & Wikman 2012 [14] & 3652 & $97.6(96.9,98.2)$ & $98.9(98.2,99.4)$ \\
\hline & Clausen 2012 [15] & 2312 & $99.9(99.5,100)$ & $99.3(98.7,100)$ \\
\hline & This study & 337 & 97.1 & 100 \\
\hline \multirow[t]{2}{*}{ Droplet digital PCR } & Sillence 2015 [18] & $22^{a}$ & 100 & 95.5 \\
\hline & Sillence 2015 [18] & $24^{\mathrm{b}}$ & 100 & 100 \\
\hline \multirow[t]{2}{*}{ NGS } & $\begin{array}{c}\text { Wienzek-Lischka } \\
2015 \text { [21] }\end{array}$ & 4 & & \\
\hline & Orzińska 2019 [22] & 13 & & \\
\hline \multirow[t]{2}{*}{ End-point QF PCR } & Kimura 2008 [19] & 13 & & \\
\hline & This study & 337 & 100 & 98.6 \\
\hline
\end{tabular}

n-number of evaluated participants, a-blood samples from RhD-negative pregnant women collected in EDTA tubes, b-blood samples from RhD-negative pregnant women collected in BCTs tubes, ${ }^{*}$-when is provided, NGS-Next Generation Sequencing.

Accuracy characteristics were similar for both methods.

The real-time PCR does not need a capillary electrophoresis separation step and so it takes about $2 \mathrm{~h}$ less. 
On the other hand, the advantage of QFPCR lies in its direct confirmation of PCR specificity using the length of PCR fragments. In addition, an AMELY-specific probe can be used in male fetuses as a cffDNA control and quantificator.

The only currently published studies in the Czech Republic were on small groups of patients. Hromadníkova et al. analyzed a group of 45 pregnant women using real-time PCR [58]. Svobodová et al. compared dd PCR and real-time PCR on a group of 35 pregnant women [17].

Our results are comparable to those published (see Table 6).

\section{Conclusions}

The main goal of this study was to asses and compare possible clinical utilization of two methodological approaches of noninvasive fetal RHD genotyping in RhD-negative pregnant women. The study proved there was a minimal discrepancy between the RhD phenotype and the RHD genotype for the Czech population and since both the methods showed excellent power to predict the fetal RHD genotype from maternal plasma, it is possible to introduce them into clinical practice.

Author Contributions: Study design, J.B, M.L., and R.V.; RhD phenotyping, I.H.; plasma collection, R.K. and E.K.; real-time PCR and QF PCR analyses, J.B. and R.V.; clinical data collection, M.L., M.S., V.D., T.K., and M.P.; statistics, L.D. All authors have read and agreed to the published version of the manuscript.

Funding: This research was funded by a grant from the Ministry of Health of the Czech Republic: conceptual development of research organization MH CZ-DRO (FNOL, 00098892) 2020 and by grant agency IGA MZ CR: NT12225.

Conflicts of Interest: All the authors declare no conflict of interest.

\section{References}

1. Avent, N.D.; Reid, M.E. The Rh blood group system: A review. Blood 2000, 95, 375-387. [CrossRef] [PubMed]

2. de Haas, M.; Finning, K.; Massey, E.; Roberts, D.J. Anti-D prophylaxis: Past, present and future. Transfus. Med. 2014, 24, 1-7. [CrossRef] [PubMed]

3. de Haas, M.; Thurik, F.F.; Koelewijn, J.M.; van der Schoot, C.E. Haemolytic disease of the fetus and newborn. Vox Sang. 2015, 109, 99-113. [CrossRef] [PubMed]

4. van der Schoot, C.E.; de Haas, M.; Clausen, F.B. Genotyping to prevent Rh disease: Has the time come? Curr. Opin. Hematol 2017, 24, 544-550. [CrossRef] [PubMed]

5. Kent, J.; Farrell, A.-M.; Soothill, P. Routine administration of Anti-D: The ethical case for offering pregnant women fetal RHD genotyping and a review of policy and practice. BMC Pregnancy Childbirth 2014, 14, 87. [CrossRef]

6. Kratochvílová, T.; Holusková, I.; Durdová, V.; Strašilová, P.; Ĺubušký, M. Klinický význam neinvazivního stanovení RHD a RHCE genotypu plodu v managementu těhotenství s rizikem rozvoje hemolytické nemoci plodu a novorozence [The clinical significance of the non-invasive fetal RHD and RHCE genotype assessment in the management of pregnancies at risk of hemolytic disease of the fetus and newborn]. J. Postgrad. Med. 2016, 18, 362-369.

7. Innan, H. A two-locus gene conversion model with selection and its application to the human RHCE and RHD genes. Proc. Natl. Acad. Sci. USA 2003, 100, 8793-8798. [CrossRef]

8. Palomaki, G.E.; Kloza, E.M.; Lambert-Messerlian, G.M.; Haddow, J.E.; Neveux, L.M.; Ehrich, M.; van den Boom, D.; Bombard, A.T.; Deciu, C.; Grody, W.W.; et al. DNA sequencing of maternal plasma to detect Down syndrome: An international clinical validation study. J. Genet. Med. 2011, 13, 913-920. [CrossRef]

9. de Haas, M.; Thurik, F.F.; van der Ploeg, C.P.B.; Veldhuisen, B.; Hirschberg, H.; Soussan, A.A.; Woortmeijer, H.; Abbink, F.; Page-Christiaens, G.C.M.L.; Scheffer, P.G.; et al. Sensitivity of fetal RHD screening for safe guidance of targeted anti-D immunoglobulin prophylaxis: Prospective cohort study of a nationwide programme in the Netherlands. BMJ 2016, 355. [CrossRef]

10. Haimila, K.; Sulin, K.; Kuosmanen, M.; Sareneva, I.; Korhonen, A.; Natunen, S.; Tuimala, J.; Sainio, S. Targeted antenatal anti-D prophylaxis program for $\mathrm{RhD}$ - negative pregnant women: Outcome of the first two years of a national program in Finland. Acta Obstet. Gynecol. Scand. 2017, 96, 1228-1233. [CrossRef] 
11. Hyland, C.A.; Millard, G.M.; O’Brien, H.; Schoeman, E.M.; Lopez, G.H.; McGowan, E.; Tremellen, A.; Puddephatt, R.; Gaerty, K.; Flower, R.L.; et al. Non-invasive fetal RHD genotyping for RhD negative women stratified into $R H D$ gene deletion or variant groups: Comparative accuracy using two blood collection tube types. Pathology 2017, 49, 757-764. [CrossRef] [PubMed]

12. Clausen, F.B.; Barrett, A.N.; Noninvasive Fetal RHD Genotyping EQA2017 Working Group. Noninvasive fetal RHD genotyping to guide targeted anti-D prophylaxis-an external quality assessment workshop. Vox Sang. 2019, 114, 386-393. [CrossRef] [PubMed]

13. Moezzi, L.; Keshavarz, Z.; Ranjbaran, R.; Aboualizadeh, F.; Behzad-Behbahani, A.; Abdullahi, M.; Ramezani, A.; Samsami, A.; Sharifzadeh, S. Fetal RHD genotyping using real-time polymerase chain reaction analysis of cell-free fetal DNA in pregnancy of RhD negative women in South of Iran. Int. J. Fertil. Steril. 2016, 10, 62-70. [CrossRef] [PubMed]

14. Wikman, A.T.; Tiblad, E.; Karlsson, A.; Olsson, M.L.; Westgren, M.; Reilly, M. Noninvasive single-exon fetal RHD determination in a routine screening program in early pregnancy. Obstet. Gynecol. 2012, 120, 227-234. [CrossRef]

15. Clausen, F.B.; Christiansen, M.; Steffensen, R.; Jørgensen, S.; Nielsen, C.; Jakobsen, M.A.; Madsen, R.D.; Jensen, K.; Krog, G.R.; Rieneck, K.; et al. Report of the first nationally implemented clinical routine screening for fetal RHD in D- pregnant women to ascertain the requirement for antenatal RhD prophylaxis. Transfusion 2012, 52, 752-758. [CrossRef]

16. Böhmová, J.; Vodička, R.; L'ubušký, M.; Studničková, M.; Holusková, I.; Vrtěl, R.; Kratochvílová, R.; Frydrychová, M.; Krejčiříková, E.; Filipová, H. Stanovení RHD genotypu plodu z plazmy periferní krve těhotné ženy a posouzení citlivosti nových diagnostických postupů pro zavedení do klinické praxe [RHD genotyping from cell-free fetal DNA circulating in pregnant women peripheral blood and sensitivity assessment of innovated diagnostic approaches for introduction into the clinical practice]. Ces. Gynek. 2013, 78, 32-40.

17. Svobodová, I.; Pazourková, E.; Hořínek, A.; Novotná, M.; Calda, P.; Korabečná, M. Performance of Droplet Digital PCR in non-invasive fetal RHD genotyping-comparison with a routine real-time PCR based approach. PLoS ONE 2015, 10, e0142572. [CrossRef]

18. Sillence, K.A.; Roberts, L.A.; Hollands, H.J.; Thompson, H.P.; Kiernan, M.; Madgett, T.E.; Welch, C.R.; Avent, N.D. Fetal sex and RHD genotyping with digital PCR demonstrates greater sensitivity than real-time PCR. Clin. Chem. 2015, 61, 1399-1407. [CrossRef]

19. Kimura, M.; Sato, C.; Hara, M.; Ishihara, O.; Ikebuchi, K. Noninvasive fetal RHD genotyping by maternal plasma with capillary electrophoresis. Transfusion 2008, 48, 1156-1163. [CrossRef]

20. Wienzek-Lischka, S.; Bachmann, S.; Fröhner, V.; Bein, G. Potential of next-generation sequencing in noninvasive fetal molecular blood group genotyping. Transfus. Med. Hemother. 2020, 47, 14-22. [CrossRef]

21. Wienzek-Lischka, S.; Krautwurst, A.; Fröhner, V.; Hackstein, H.; Gattenlöhner, S.; Bräuninger, A.; Axt-Fliedner, R.; Degenhardt, J.; Deisting, C.; Santoso, S.; et al. Noninvasive fetal genotyping of human platelet antigen-1a using targeted massively parallel sequencing. Transfusion 2015, 55, 1538-1544. [CrossRef] [PubMed]

22. Orzińska, A.; Guz, K.; Mikula, M.; Kluska, A.; Balabas, A.; Ostrowski, J.; Uhrynowska, M.; Kopeć, I.; Debska, M.; Luterek, K.; et al. Prediction of fetal blood group and platelet antigens from maternal plasma using next-generation sequencing. Transfusion 2020, 60, 884. [CrossRef] [PubMed]

23. Vodička, R.; Vrtěl, R.; Scheinost, O.; Zapletalová, J.; Dušek, L.; Geierová, M.; Šantavý, J. Refined quantitative fluorescent PCR of Y-chromosome DNA sequences mosaics in Turner's syndrome patients-alternative to real-time PCR. J. Biochem. Biophys. Methods 2004, 60, 151-162. [CrossRef] [PubMed]

24. Vodička, R.; Vrtěl, R.; Procházka, M.; Šantavá, A.; Dušek, L.; Vrbická, D.; Singh, R.; Krejčiříková, E.; Schneiderová, E.; Šantavý, J. Analýza volné fetální DNA v maternální plazme s vyuźitím STR lokusů [Analysis of free foetal DNA in maternal plasma using STR loci]. Cas. Lek. Cesk. 2006, 145, 133-137. [PubMed]

25. Page, K.; Hava, N.; Ward, B.; Brown, J.; Guttery, D.S.; Ruangpratheep, C.; Blighe, K.; Sharma, A.; Walker, R.A.; Coombes, R.C.; et al. Detection of HER2 amplification in circulating free DNA in patients with breast cancer. Br. J. Cancer 2011, 104, 1342-1348. [CrossRef] [PubMed] 
26. Sikora, A.; Zimmermann, B.G.; Rusterholz, C.; Birri, D.; Kolla, V.; Lapaire, O.; Hoesli, I.; Kiefer, V.; Jackson, L.; Hahn, S. Detection of increased amounts of cell-free fetal DNA with short PCR amplicons. Clin. Chem. 2010, 56, 136-138. [CrossRef]

27. Nygren, A.O.H.; Dean, J.; Jensen, T.J.; Kruse, S.; Kwong, W.; van den Boom, D.; Ehrich, W. Quantification of fetal DNA by use of methylation-based DNA discrimination. Clin. Chem. 2010, 56, 1627-1635. [CrossRef]

28. Fan, H.C.; Blumenfeld, Y.J.; Chitkara, U.; Hudgins, L.; Quake, S.R. Analysis of the size distributions of fetal and maternal cell-free DNA by paired-end sequencing. Clin. Chem. 2010, 56, 1279-1286. [CrossRef]

29. Lun, F.M.F.; Chiu, R.W.K.; Chan, K.C.A.; Leung, T.Y.; Lau, T.K.; Lo, Y.M.D. Microfluidics digital PCR reveals a higher than expected fraction of fetal DNA in maternal plasma. Clin. Chem. 2008, 54, 1664-1672. [CrossRef]

30. Vodička, R.; Vrtěl, R.; Dušek, L.; Procházka, M.; Schneiderová, E.; Vrbická, D.; Krejčiříková, E.; Dhaifalah, I.; Šantavá, A.; Šantavý, J. Refined fluorescent STR quantification of cell-free fetal DNA during pregnancy in physiological and Down syndrome fetuses. Prenat. Diagn. 2008, 28, 425-433. [CrossRef]

31. Denis, M.G.; Knol, A.-C.; Théoleyre, S.; Vallée, A.; Dréno, B. Efficient detection of BRAF mutation in plasma of patients after long-term storage of blood in cell-free DNA blood collection tubes. Clin. Chem. 2015, 61, 886-888. [CrossRef] [PubMed]

32. Toro, P.V.; Erlanger, B.; Beaver, J.A.; Cochran, R.L.; VanDenBerg, D.A.; Yakim, E.; Cravero, K.; Chu, D.; Zabransky, D.J.; Wong, H.Y.; et al. Comparison of cell stabilizing blood collection tubes for circulating plasma tumor DNA. Clin. Biochem. 2015, 48, 993-998. [CrossRef] [PubMed]

33. van Dessel, L.F.; Beije, N.; Helmijr, J.C.A.; Vitale, S.R.; Kraan, J.; Look, M.P.; de Wit, R.; Sleijfer, S.; Jansen, M.P.H.M.; Martens, J.W.M.; et al. Application of circulating tumor DNA in prospective clinical oncology trials-standardization of preanalytical conditions. Mol. Oncol. 2017, 11, 295-304. [CrossRef]

34. Barrett, A.N.; Zimmermann, B.G.; Wang, D.; Holloway, A.; Chitty, L.S. Implementing prenatal diagnosis based on cell-free fetal DNA: Accurate identification of factors affecting fetal DNA yield. PLoS ONE 2011, 6, e25202. [CrossRef]

35. Board, R.E.; Williams, V.S.; Knight, L.; Shaw, J.; Greystoke, A.; Ranson, M.; Dive, C.; Blackhall, F.H.; Hughes, A. Isolation and extraction of circulating tumor DNA from patients with small cell lung cancer. Ann. N. Y. Acad. Sci. 2008, 1137, 98-107. [CrossRef]

36. Kadam, S.K.; Farmen, M.; Brandt, J.T. Quantitative measurement of cell-free plasma DNA and applications for detecting tumor genetic variation and promoter methylation in a clinical setting. J. Mol. Diagn. 2012, 14, 346-356. [CrossRef]

37. Norton, S.E.; Lechner, J.M.; Williams, T.; Fernando, M.R. A stabilizing reagent prevents cell-free DNA contamination by cellular DNA in plasma during blood sample storage and shipping as determined by digital PCR. Clin. Biochem. 2013, 46, 1561-1565. [CrossRef] [PubMed]

38. van Ginkel, J.H.; van den Broek, D.A.; van Kuik, J.; Linders, D.; de Weger, R.; Willems, S.M.; Huibers, M.H.M. Preanalytical blood sample workup for cell-free DNA analysis using Droplet Digital PCR for future molecular cancer diagnostics. Cancer Med. 2017, 6, 2297-2307. [CrossRef]

39. Liggett, T.; Melnikov, A.; Yi, Q.-L.; Replogle, C.; Brand, R.; Kaul, K.; Talamonti, M.; Abrams, R.A.; Levenson, V. Differential methylation of cell-free circulating DNA among patients with pancreatic cancer versus chronic pancreatitis. Cancer 2010, 116, 1674-1680. [CrossRef]

40. Christensen, E.; Nordentoft, I.; Vang, S.; Birkenkamp-Demtröder, K.; Jensen, J.B.; Agerbæk, M.; Pedersen, J.S.; Dyrskjøt, L. Optimized targeted sequencing of cell-free plasma DNA from bladder cancer patients. Sci. Rep. 2018, 8. [CrossRef]

41. Wang, B.G.; Huang, H.-Y.; Chen, Y.-C.; Bristow, R.E.; Kassauei, K.; Cheng, C.-C.; Roden, R.; Sokoll, L.J.; Chan, D.W.; Shih, E.-M. Increased plasma DNA integrity in cancer patients. Cancer Res. 2003, 63, 3966-3968.

42. Ren, C.C.; Miao, X.H.; Yang, B.; Zhao, L.; Sun, R.; Song, W.Q. Methylation status of the fragile histidine triad and E-cadherin genes in plasma of cervical cancer patients. Int. J. Gynecol. Cancer 2006, 16, 1862-1867. [CrossRef]

43. Pinzani, P.; Salvianti, F.; Zaccara, S.; Massi, D.; De Giorgi, V.; Pazzagli, M.; Orlando, C. Circulating cell-free DNA in plasma of melanoma patients: Qualitative and quantitative considerations. Clin. Chim. Acta 2011, 412, 2141-2145. [CrossRef] [PubMed]

44. Kamel, A.M.; Teama, S.; Fawzy, A.; El Deftar, M. Plasma DNA integrity index as a potential molecular diagnostic marker for breast cancer. Tumour Biol. 2016, 37, 7565-7572. [CrossRef] [PubMed] 
45. Leng, S.; Zheng, J.; Jin, Y.; Zhang, H.; Zhu, Y.; Wu, J.; Xu, Y.; Zhang, P. Plasma cell-free DNA level and its integrity as biomarkers to distinguish non-small cell lung cancer from tuberculosis. Clin. Chim. Acta 2018, 477, 160-165. [CrossRef] [PubMed]

46. Hu, P.; Liang, D.; Chen, Y.; Lin, Y.; Qiao, F.; Li, H.; Wang, T.; Peng, C.; Luo, D.; Liu, H.; et al. An enrichment method to increase cell-free fetal DNA fraction and significantly reduce false negatives and test failures for non-invasive prenatal screening: A feasibility study. J. Transl. Med. 2019, 17. [CrossRef] [PubMed]

47. Jain, M.; Balatsky, A.V.; Revina, D.B.; Samokhodskaya, L.M. Direct comparison of QIAamp DSP Virus Kit and QIAamp Circulating Nucleic Acid Kit regarding cell-free fetal DNA isolation from maternal peripheral blood. Mol. Cell Probes. 2019, 43, 13-19. [CrossRef]

48. Wagner, F.F.; Gassner, C.; Müller, T.H.; Schönitzer, D.; Schunter, F.; Flegel, W.A. Molecular basis of weak D phenotypes. Blood 1999, 93, 385-393. [CrossRef]

49. Flegel, W.A. Molecular genetics and clinical applications for RH. Transfus. Apher. Sci. 2011, 44, 81-91. [CrossRef]

50. Colin, Y.; Chérif-Zahar, B.; Le van Kim, C.; Raynal, V.; Van Huffel, V.; Cartron, J.P. Genetic basis of the $\mathrm{RhD}$-positive and $\mathrm{RhD}$ - negative blood group polymorphism as determined by Southern analysis. Blood 1991, 78, 2747-2752. [CrossRef]

51. Wagner, F.F.; Flegel, W.A. RHD gene deletion occurred in the Rhesus box. Blood 2000, 95, 3662-3668. [CrossRef] [PubMed]

52. Pirelli, K.J.; Pietz, B.C.; Johnson, S.T.; Pinder, H.L.; Bellissimo, D.B. Molecular determination of RHD zygosity: Predicting risk of hemolytic disease of the fetus and newborn related to anti-D. Prenat. Diagn. 2010, 30, 1207-1212. [CrossRef]

53. Daniels, G. Human Blood Groups, 2nd ed.; Blackwell Science: Oxford, UK, 2002.

54. Singleton, B.K.; Green, C.A.; Avent, N.D.; Martin, P.G.; Smart, E.; Daka, A.; Narter-Olaga, E.G.; Hawthorne, L.M.; Daniels, G. The presence of an RHD pseudogene containing a 37 base pair duplication and a nonsense mutation in Africans with the Rh D-negative blood group phenotype. Blood 2000, 95, 12-18. [CrossRef] [PubMed]

55. Faas, B.H.; Beckers, E.A.; Wildoer, P.; Ligthart, P.C.; Overbeeke, M.A.; Zondervan, H.A.; von dem Borne, A.E.; van der Schoot, C.E. Molecular background of vs. and weak C expression in blacks. Transfusion 1997, 37, $38-44$. [CrossRef] [PubMed]

56. Daniels, G.L.; Faas, B.H.; Green, C.A.; Smart, E.; Maaskant-van Wijk, P.A.; Avent, N.D.; Zondervan, H.A.; von dem Borne, A.E.; van der Schoot, C.E. The vs. and V blood group polymorphisms in Africans: A serologic and molecular analysis. Transfusion 1998, 38, 951-958. [CrossRef] [PubMed]

57. Takahashi, K.; Migita, O.; Sasaki, A.; Nasu, M.; Kawashima, A.; Sekizawa, A.; Sato, T.; Ito, Y.; Sago, H.; Okamoto, A.; et al. Amplicon Sequencing-Based Noninvasive Fetal Genotyping for RHD-Positive D Antigen-Negative Alleles. Clin. Chem. 2019, 65, 1307-1316. [CrossRef]

58. Hromadníková, I.; Veselá, K.; Benešová, B.; Nekovářová, D.; Dušková, D.; Vlk, R.; Špálová, I.; Gerychová, R.; Hakenová, A.; Rosenbaumová, Z.; et al. Non-invasive fetal RHD and RHCE genotyping from maternal plasma in alloimmunized pregnancies. Prenat. Diagn. 2005, 25, 1079-1083. [CrossRef]

(C) 2020 by the authors. Licensee MDPI, Basel, Switzerland. This article is an open access article distributed under the terms and conditions of the Creative Commons Attribution (CC BY) license (http://creativecommons.org/licenses/by/4.0/). 